\title{
PERSPECTIVES ON DISRUPTIVE INNOVATIONS
}

\author{
Arun Kumaraswamy* \\ Florida International University \\ College of Business \\ Department of International Business \\ 11200 SW 8th Street, Miami, FL 33199. USA. \\ Tel: + 13053483780 \\ Email: akumaras@fiu.edu \\ Raghu Garud \\ The Pennsylvania State University \\ Smeal College of Business \\ Management and Organization Department \\ 431 Business Building, University Park PA 16802. USA. \\ Tel: +1 8148634534 \\ Email: rgarud@psu.edu \\ Shahzad (Shaz) Ansari \\ University of Cambridge \\ Cambridge Judge Business School \\ Trumpington Street, Cambridge CB2 1AG. UK. \\ Tel: +44 (0)1223 768128 \\ Email: s.ansari@jbs.cam.ac.uk
}

July 16, 2018

\section{To appear in Journal of Management Studies Special Issue Managing in the Age of Disruptions}

\footnotetext{
* This a fully collaborative effort, with authors listed in reverse alphabetical order. We, the guest editors and contributors to this special issue, are indebted to Dries Faems, the Journal of Management Studies handling editor, and the many anonymous reviewers for their generous and constructive feedback.
} 


\title{
PERSPECTIVES ON DISRUPTIVE INNOVATIONS
}

\begin{abstract}
Everyday experiences speak to the accelerated pace of innovation in this era of continual change. Sometimes, innovations enhance the value of existing products and services. At other times, they render existing business models obsolete, disrupt value-networks, prompt providers to rethink who their customers are, and lead customers to rethink what they value. What does it mean to manage in such a world of disruptive changes, and how might we research this phenomenon? Together with the contributors to this special issue, we anchor, explore and extend the meanings associated with the concept of disruptive innovation. In particular, we discuss several perspectives on disruption - evolutionary, relational, temporal and framing - that culminate in a performative (as opposed to a predictive) approach to thinking about the phenomenon. In doing so, our intention is to open up the agenda for both researchers and practitioners.
\end{abstract}

Key words: Disruption, disruptive innovation, ecosystems, platforms, process, performativity, temporality 
It is hard to deny that we are living in an age of continual disruptions, defined vernacularly as fundamental changes that disturb or re-order the ways in which firms and their ecosystems operate. In the 1980s, researchers studying technological innovation focused on (among other issues) transilience (Abernathy and Clark, 1985), which culminated in the emergence of dominant designs (Tushman and Anderson, 1986; Utterback and Abernathy, 1975). The 1990s saw the advent of disruptive technologies, a concept that Christensen (1997) introduced to explore why incumbents may lose ground to innovations introduced by new entrants. This century is best described as an era of continual disruption in which technological innovations and new business model changes are affecting not just individual firms, but entire industries and ecosystems.

In this introductory essay, we open up the agenda for studying the process of continual disruption. To anchor our arguments, we begin with an overview of the classical evolutionary perspective on disruption. Next, we extend this classical view by considering several additional perspectives on the phenomenon. For instance, by endogenizing the contexts within which disruption unfolds, we offer a relational perspective that considers ecosystem dynamics. Moreover, by considering the process dynamics associated with disruption, we provide a temporal perspective. Considerations of relationality and temporality suggest a heterogeneity of responses and strategies by disruptors and incumbents to innovations as they unfold over time, which leads to a framing perspective. In combination, these perspectives suggest the utility of taking a performative, as opposed to a predictive, approach to disruption. After presenting the performative approach, we introduce the papers featured in this special issue, each of which deepens and broadens our understanding of the phenomenon.

\section{EVOLUTIONARY PERSPECTIVE ON DISRUPTION}


Christensen (1997) offered a theory on disruptive technologies (later disruptive innovations) in a book evocatively titled The Innovator's Dilemma. This theory highlights how challengers can offer what he labeled as disruptive technologies (or innovations) to unseat established incumbents. The challenger begins by offering innovations that are inferior in terms of features or performance, but also cheaper or more accessible than products and services in the mainstream market. Because these "inferior" innovations appeal primarily to niche customer segments that are overserved or ignored by established incumbents, the challenger is able to circumvent selection environments constituting mainstream markets.

Although it may be possible for the incumbent to offer an equivalent innovation to compete with the challenger, doing so would cannibalize its profitable offerings in mainstream markets. Faced with this innovator's dilemma, the incumbent ignores the challenger and its innovation, and continues to improve the performance of its existing products and services. Over time, though, the performance of the challenger's innovation gradually improves, while at the same time remaining cheaper or more accessible than the incumbent's products or services. At a critical juncture, the disruptive innovation becomes good enough to serve mainstream customers, who then migrate to this cheaper or more accessible alternative. The incumbent, wedded to its long-standing offerings and business model, then finds it almost impossible to compete with the challenger and suffers declining performance. To avoid this outcome, incumbents are advised to "develop a disruption of your own before it's too late to reap the rewards of participation in new, high-growth markets" by setting up a separate organizational unit to manage the innovation (Christensen, 1997).

Despite and because of its evocative framing, the theory of disruption has received its share of criticism (e.g., Danneels, 2004; King and Baatartogtokh, 2015; Lepore, 2014; Tellis, 2006; Sood and Tellis, 2011). These studies question the definition of this concept, the assumptions on which the theory is based, the sampling method and the validity of supporting 
evidence, and the theory's predictive power. Subsequently, Christensen and his colleagues addressed several of these criticisms (Christensen, 2006; Christensen, Raynor and McDonald, 2015) by offering clarifications and expanding the definition of disruption to include innovative business models and new market footholds in addition to low-end disruptions. However, the theory (as originally framed) does not adequately address the dynamics of a number of innovations such as Apple's iPhone or Uber's ride-hailing platform (also see The Economist, 2015). Many of these innovations are systemic, serve as platforms for others to build on, and disrupt existing relationships among the members of entire industries and ecosystems instead of affecting just specific incumbents (as in the case of standalone products or services offered by individual firms). To understand the dynamics involved, and to meaningfully extend the original definition to apply to such innovations, we must adopt a relational perspective on the phenomenon, which we explore next.

\section{A RELATIONAL PERSPECTIVE ON DISRUPTION}

To establish the foundations for a relational perspective on disruption, we begin with Teece's (1986) work, which emphasized the critical role of complementary assets in the successful commercialization of innovations. To the extent that innovators can still appropriate value from their innovations without internalizing all complementary assets, they may rely on other to provide these assets. Scholars have labeled the resultant network of interdependent firms, as business ecosystems (e.g., Adner, 2012; Iansiti and Levien, 2004; Moore, 1993). Together, these firms establish not only the value proposition for buyers, but also how such value is created and captured by each firm (Brandenburger and Nalebuff, 1996). In addition, other actors including regulators, evaluators and other stakeholders play an important role in ecosystem dynamics (Garud and Karnøe, 2013; Van de Ven and Garud, 1989). 
Business ecosystems are particularly relevant in systemic industries wherein different components or modules of a system, i.e., a technology or product platform, are offered by different firms, and need to be compatible with one another to generate utility. Innovations may result in changes to the system's architecture, i.e., the form and function of system components, and how they interface and interact with one another. In such cases, existing roles, relationships, rules and transactions within the ecosystem may be significantly impacted (Garud and Munir, 2008; Jacobides, Knudsen, Augier, 2006).

Moreover, digital innovations, characterized by convergence and generativity (Yoo, Boland, Lyytinen and Majchrzak, 2012) are blurring boundaries between industries and sectors (e.g., Education and Entertainment), consumers and producers (e.g., Sharing Economy), humans and machines (e.g., Artificial Intelligence), products and services (servitization), and the physical and the digital (e.g., the Internet of Things). In such cases too, extant relationships among ecosystem members may be reconfigured radically. For instance, the recent emergence of a mobility ecosystem around "autonomous vehicles" (selfdriving cars) has impacted not just traditional automakers, but also blurred the boundaries between technology firms, energy companies, and insurance companies (Yin, Ansari and Akhtar, 2017). Likewise, Uber's business model innovation, besides disrupting taxicab companies, has transformed the transportation industry ecosystem by blurring the line between service providers and users that even regulators have had a hard time categorizing it.

To explain such phenomena, there is utility in explicitly considering the impact of innovations on the relational interdependencies across the entire ecosystem (Adner and Kapoor, 2010; Dougherty and Dunne, 2011; Garud and Kumaraswamy, 1995; Jacobides, Cennamo and Gawer, 2018). Such a relational view reveals several challenges for firms defending their positions in an existing market (henceforth incumbents), and for firms (whether incumbents or new entrants) attempting to disrupt existing markets (henceforth 
disruptors) (see Ansari and Krop, 2012; Kapoor and Klueter, 2015). For incumbents, the advent of innovations can disrupt existing relationships. For instance, the introduction of the quartz movement disrupted the watchmaking production networks in Switzerland (Glasmeier, 1991; Raffaelli, 2018). Similarly, the "Open Access" model in publishing that allows free access and unrestricted use of academic literature disrupts the relationship between publishers, authors, universities and readers under the "Toll Access" model, wherein readers or universities that subscribe to these publications need to pay to access them (Thananusak and Ansari, 2018).

For disruptors, especially in systemic industries characterized by multi-sided platforms (Gawer and Cusumano, 2014; Hagiu, 2014; Nambisan, Siegel and Kenney, 2018; Parker, Van Alstyne and Choudary, 2016; Rochet and Tirole, 2003), a critical task is to stitch together a new viable ecosystem around the disruptive innovation. This is a significant challenge because new entrants often need to gain access to complementary resources from the very ecosystem incumbents they disrupt. This disruptor's dilemma (Ansari, et al, 2016; see also Gans, 2016) is particularly critical for disruptors like TiVo and Spotify, which have a high degree of relational dependency on incumbents. Other disruptors such as Airbnb and Uber have less dependency on incumbents but still need to address dependencies on other stakeholders such as regulators. Examples include ongoing battles between e-cigarette entrepreneurs and the U.S. Food and Drug Administration (FDA) as to whether or not ecigarettes should be regulated on par with traditional cigarettes (Tharchen and Garud, 2017), and Uber's battles with regulators on the categorization of its services.

An additional challenge is that different members (or sides) of the ecosystem coalescing around a platform have motivations and interests that may diverge even as they together seek to create value. Not surprisingly, some relationships are cooperative and some are competitive. Yet others, however, are co-opetitive (Brandenburger and Nalebuff, 1996; 
Gnyawali and Park, 2011), i.e., cooperative and competitive at the same time. While collaborative relationships have been shown to have a positive impact on innovative performance, it depends on the nature of the partner(s) involved (Faems, Looy and Debackere, 2005). Dealing with the tensions created by such diverse relationships is not trivial, whether for incumbents or disruptors.

When we consider the actions and reactions of the multiple stakeholders within an ecosystem, the outcomes of disruptive innovations are difficult to predict. An implication for disruptors, especially small startups, is that they cannot wait for the process to settle down. New technologies might emerge that 'disrupt' the disruptive innovations, or incumbents might adapt or even co-opt the disruptive innovation for their own benefit. Therefore, disruptors need to forge ahead despite and even because of the indeterminacies involved. These observations lead to temporal considerations (besides relational) that we discuss next.

\section{A TEMPORAL PERSPECTIVE ON DISRUPTION}

Scholars have acknowledged that disruption is an overall process of "evolution of [the disruptive] product or service over time" (Christensen, et al., 2015, p. 6). This process is best understood as a path that disruptive innovations follow "from the fringe to the mainstream", and ought to be considered disruptive even if they do not end up unseating the incumbents. Here we see the beginnings of a 'processual' rather than an 'outcome-based' explanation of disruptive innovation, which introduces a temporal facet to disruption.

To extend theorization of disruption from a temporal perspective, we consider why incumbents are unable or unwilling to recognize and respond to the threat of disruption in real time, only to be disrupted over time. Various explanations have been offered. For instance, Christensen highlights the economic dilemma that incumbents confront in introducing disruptive innovations that are not aligned with their business models and threaten cannibalization of their existing offerings. Cognitive explanations (Benner and 
Tripsas, 2012; Kaplan and Tripsas, 2008; Tripsas and Gavetti, 2000) suggest that incumbents ignore at their peril innovations that threaten their identities, templates, and mental models. Additionally, behavioral explanations portray incumbents as being trapped by core rigidities and organizational myopia (Danneels, 2011; Leonard-Barton, 1992; Levinthal and March, 1993). More recently, scholars have proposed affective reasons for incumbents' inability to respond in real time, as was the case with Nokia in the mobile telephony market wherein top and middle managers' shared emotions during the smartphone innovation process influenced the company's ability to respond (Vuori and Huy, 2016).

Together, these explanations lead to a richer understanding of how and why incumbents fall prey to "errors of omission" (Garud, Nayyar and Shapira, 1997) by failing to take a long-term view. In this regard, Schumpeter (1942/1994: 83) noted: "[S]ince we are dealing with a process whose every element takes considerable time in revealing its true features and ultimate effects, there is no point in appraising the performance of that process ex visu of a given point of time; we must judge its performance over time. ..". Accordingly, incumbents are advised to reduce errors of omission by pursuing innovations that could be disruptive in the future well before others. However, as we have noted, successfully developing and then commercializing a disruptive innovation is a long drawn out process that could well end up in failure, an "error of commission" that any potential disruptor would like to minimize.

How, then, can firms (incumbents and disruptors) ensure fewer errors of omission while also minimizing errors of commission? Usher's (1954) process of cumulative synthesis provides the micro foundations of one such perspective. In particular, Usher offered four intertwined mechanisms driving the emergence of novelty, which he labeled as "perception of an incomplete pattern", the "setting of the stage", "act of insight", and "critical revision". 
These mechanisms help us to understand the micro processes associated with disruptive innovation.

For instance, to reduce errors of omission, incumbents must cultivate the capacity to read weak signals about potentially disruptive innovations and explore options before it is too late. To do so, it is critical to "set the stage", by putting in place mechanisms to seek out ideas with potential future value and keep them alive for activation at an appropriate time. Such mechanisms include 3M's technology platforms that preserved intermediate insights and artifacts from experiments (Garud, Gehman and Kumaraswamy, 2011), or P\&G's “Connect and Develop" model (Sakkab, 2002) that connects ideas and resources outside the firm with those inside. Setting the stage allows firms to deal with both asynchrony, i.e., different elements emerging at different rates and at different times (see Ansari and Garud, 2009 for how this unfolded during technological transitions in the field of mobile telephony), and diachrony, i.e., ideas for which there are no immediate applications or those considered "mistakes" or "failures" at present becoming valuable in the future (just as ideas considered promising at present turning out to be false-starts on further analysis).

Setting the stage also makes it possible for "acts of insights" to occur at opportune moments or Kairos, the Greek god of opportunity or luck, a complement to chronological or sequential time personified by the god Chronos. For instance, 3M cultivated Kairos through its $15 \%$ "bootlegging rule", which allowed employees to use a portion of their work time to explore their own ideas, to develop a number of new products including a new kind of abrasive (Trizact) that disrupted its existing abrasive product (Garud et al., 2011). Similarly, as the disruptor, Google too cultivated Kairos through its $20 \%$ time for participative experimentation to disrupt existing email platforms with its Gmail platform (Garud and Karunakaran, 2018; see also Dougherty, 2016). 
An observation offered by Spence Silver of 3M (who is credited with discovering the substance that led to 3M's Post-it Notes) offers additional insights on the process. Silver noted, "Things build up and you begin to see the options that [a] discovery creates." (Lindahl, 1998). In other words, each act of insight is but an intermediate step which opens up new opportunities and challenges. Addressing these emergent opportunities and challenges results in transformations through further innovation, i.e., "critical revision" in Usher's terms. For instance, in the case of TiVo, the DVR technology and the associated business model had to be updated to deal with the television industry ecosystem's pressures and evolution. Such critical revision forms the basis for strategies like "pivoting", which is discussed in the entrepreneurship literature (Grimes, 2017; Ries, 2011).

\section{A FRAMING PERSPECTIVE ON DISRUPTION}

Considerations of relationality and temporality highlight a distributed process involving a multiplicity of stakeholders within an ecosystem. This conceptualization challenges traditional binary notions of innovations being either sustaining or disruptive. As Christensen (2006) has acknowledged, innovations can be sustaining to some firms and disruptive to others. Accordingly, within an ecosystem, different members (including incumbents) may be affected differently leading to a heterogeneity of responses. Such heterogeneity within the ecosystem offers the 'disruptor' an opportunity to frame its innovation to attract the support of at least some of its members. This leads us to a framing perspective.

Frames are "schemata of interpretation" that enable individuals "to locate, perceive, identify, and label" what happens in the world around them (Goffman, 1974: 21) or "principles of organization which govern the subjective meanings we assign to social events" (Goffman, 1974: 11). Framing thus directs our attention to meaning-making by highlighting certain aspects of a perceived reality to stimulate a particular understanding (Entman, 1993: 
52). Framing processes operate recursively_ both as the background shared reality to make sense of a situation and as tools for strategic and creative behavior for evoking particular meanings, mobilizing support, gaining legitimacy and persuading people (Gray, Purdy and Ansari, 2015).

In the context of technology and innovation, frames provide a socio-cognitive guide to the understanding of a technology and its developmental patterns (Dosi, 1982; Garud and Rappa, 1994) including its implementation and use in particular settings (Bijker, 1995; Kaplan and Tripsas, 2008). People make sense "not only of the nature and role of the technology itself, but the specific conditions, applications and consequences of that technology in particular contexts" (Orlikowski and Gash, 1994: 178). Any technology or innovation is understood in different ways by different stakeholders, which in turn guides the understanding of both the problem and potential solutions (Leonardi, 2011). Such an ambiguous, fluid situation offers entrepreneurs the opportunity "to shape cognitions, relations and resources in the market to their advantage" and construct new markets (Santos and Eisenhardt, 2009: 665).

We return to TiVo and its digital video recorder to illustrate these points (Ansari et al., 2016). While many incumbents saw TiVo’s DVR as a disruptive threat, television viewers loved the DVR, and several vendors and new media advertisers saw the technology as enabling potentially new, more effective ways of reaching their customers. Even a few broadcast television networks (e.g., NBC) whose business models were threatened saw future potential in the new technology. Taking advantage of this heterogeneity in perception, TiVo framed its innovation differentially. It aggressively framed its DVR as liberating television viewers from the tyranny of broadcast/cable networks and commercials, and as a gateway to more targeted, interactive and appealing advertising that viewers would voluntarily want to watch rather than skip. As it attracted more subscribers and supporters, TiVo progressively 
posed its DVR platform as an opportunity for emerging digital content providers and distributors to add value to their own products or services, while also offering more effective tools to understand viewership patterns and preferences. Over time, TiVo was able to portray itself (and be perceived by ecosystem members) as a connector enabling additional value creation in the ecosystem, instead of a disruptor destroying existing value.

However, incumbents and other stakeholders can play the framing game too. For instance, in their study of the emergence of pay TV, Gurses and Ozcan (2015) reported counter framing by incumbents who tried to delegitimize pay TV service by arguing that these services were against the public's interest. Such counter framing may lead to framing contests, with incumbents potentially having the advantage over new entrants due to their well-established relationships and arrangements with key stakeholders including regulators.

In essence, consideration of framing highlights the constitution of disruption as a phenomenon. Categorical distinctions (such as disruptive versus sustaining) do not simply report, describe or represent reality, but also constitute and perform it. For instance, Osiyevskyy and Dewald (2015) argued that the manner in which a new business model was framed (e.g., as a critical vs. a non-critical threat) influenced intentions to adopt the new business model. Likewise, in his study of the newspaper industry's response to online publishing, Gilbert (2005) showed that the framing of online publishing as a threat by traditional newspapers resulted in aggressive resource commitment to online initiatives.

\section{A PERFORMATIVE APPROACH TO EXPLORING DISRUPTION}

As may be evident from the above discussion, the meaning of the term disruption differs across different perspectives. Within Christensen's evolutionary perspective, disruption alludes to innovations that initially serve niche markets that are not attractive to incumbents but eventually enter the mainstream market to disrupt incumbents. From a relational perspective, disruption dynamics unfold not just at the level of specific or 
individual firms, but also at the inter-firm and ecosystem levels. Viewed from a temporal perspective, disruption is a process characterized by asynchrony, which in turn is linked with diachrony. Finally, from a framing perspective, the capacity of an innovation to disrupt or not is based on how the innovation is framed and experienced by the multiple actors involved at different times during the innovation's journey.

Each perspective enables us to explore and explain different facets of disruption. Moving across perspectives, we see that disruption generates complex dynamics, which cannot be envisaged upfront or understood fully even in real time. There are likely to be ups and downs, false starts and dead-ends, partial victories and triumphs as multiple actors interact with one another as innovation journeys unfold (Van de Ven, Polley, Garud \& Venkataraman, 1999). Indeed, various actors involved (whether disruptors, incumbents, complementors, regulators or analysts) are unlikely to be able to truly predict such a complex, distributed and emergent process in real time. What approach should we take to study such a phenomenon?

Building on the relational, temporal and framing perspectives discussed earlier, we now offer a performative approach to disruption. Performativity views phenomena as being constituted, de-constituted, and re-constituted through the "sayings and doings" (Austin, 1962) of multiple actors (see Garud, Gehman and Tharchen, 2017). "Sayings" include texts such as business plans and press releases, and "doings" include activities such as developing prototypes and raising capital.

Performativity, in the context of disruptive innovation, does not preclude projections. Incumbents and new entrants realize that the feasibility of a projection is contingent upon its ability to bring about felicitous conditions. Consequently, projections ought to be seen not as predictions to be judged for their accuracy but as evocative constructs of the future articulated by visionaries to jumpstart the innovation journey. From a performativity perspective, 
incumbents and disruptors explore ideas that are shaped by memories of the past, aspirations of the future and contextualized by the settings within which they operate (Emirbayer and Mische, 1998; Garud and Gehman, 2012; Reinecke and Ansari, 2017; Ricoeur, 1984). The past is not simply a collectively reproduced narrative nor does it necessarily constrain the firm in a path dependent manner. Instead, it is a "resource" that can be productively explored and exploited.

Indeed, performativity is based on an onto-epistemological position that considers the past, present and future as integrated facets of temporal agency (Ricoeur, 1984). "Reality exists in a present" (Mead 1932: I), but the immediacy of present situations is extended by our ability to imaginatively construct a sense of the past and the future (Emirbayer and Mische, 1998; Garud and Gehman, 2012; Hatch and Schultz, 2017; Hernes, 2008; Reinecke and Ansari, 2017).

The advantage of taking a performative approach to disruption is that it releases firms from the need to be "correct" or "accurate" in their projections on complex emergent phenomena. Instead, firms can focus their efforts on enacting constituted worlds, knowing fully well that their efforts are part of a larger ecology of relationships and interactions among heterogenous actants. As Callon (1998) has argued, any act of framing will generate "overflows" or unanticipated occurrences to which actors will need to respond. But, to do so, they must take into consideration the commitments they have made in the past and the possibilities that are afforded in the future by the circumstances they confront in the present (Garud, Gehman and Giuliani, 2018).

Building on these ideas, Garud et al. (2017) have argued that actors who embrace performativity are more likely to try something out to generate feedback, and then adjust their activities and framing when overflows occur. Thereby, they attempt to perform the future instead of trying to predict it. The danger for firms operating on the basis of predictions is 
that they might just choose to wait instead of probing or engaging in any experimentation whatsoever (Daft and Lengel, 1986). Even if they act, they might commit themselves prematurely to a course of action based on predictions made with meager or questionable information. Instead, a performative approach enables firms to take actions, learn, and transform as the phenomenon unfolds, thereby potentially limiting the likelihood of errors of omission and commission.

\section{PAPERS IN THIS SPECIAL ISSUE}

We now introduce the studies featured in this special issue. It is noteworthy that all empirical studies in this special issue are longitudinal in scope and offer in-depth views into the disruption process. In doing so, these studies deepen and broaden our understanding of the phenomenon (Table 1). Moreover, these studies can be explicitly or implicitly linked to the different perspectives we discussed above, with many cutting across multiple perspectives. Accordingly, we do not attempt to categorize them artificially by perspective, and instead highlight the key theoretical frames (as defined by the authors) and insights from each study.

-- Table 1 here --

Anchoring the special issue is a paper by Christensen, McDonald, Altman and Palmer titled "Disruptive Innovation: An Intellectual History and Directions for Future Research", which offers an insightful discussion of the evolution of this concept over time. As the authors highlight, the concept of disruptive innovation has invited considerable scholarly debate and research, but also gained considerable currency among practitioners. To take stock, they trace the theory's intellectual history, noting how its core principles have advanced through a process of anomaly-seeking. They also trace the theory's progression from a descriptive to a more explanatory causal theory of innovation and competitive 
response. Setting the stage for future research, the authors propose several underexplored topics such as response strategies, performance trajectories, and innovation metrics.

For incumbents, an ability to recognize and respond to disruption occurring in real time is clearly important. Yet, doing so is not easy, as the next three papers demonstrate. Khanagha, Zadeh, Mihalache and Volberda study the challenges that Ericsson faced in responding to the emergence of cloud computing, a digital platform technology, across its operations in more than 170 countries. In their paper titled "Embracing bewilderment: Responding to technological disruption in heterogeneous market environments" the authors theorize that the success of incumbents' responses depends on their capability for misalignment, which allows them to manage paradoxes in strategic direction, structure, and resource configuration associated with complex innovation processes.

Additional challenges faced by incumbents are documented by Kammerlander, Koenig and Richards in their paper titled "Why do incumbents respond heterogeneously to disruptive innovations? The interplay of domain identity and role identity". Approaching the topic from an identity theory perspective, the authors found that the emergence of disruptive innovations produced identity-driven conflicts within incumbent firms due to a mismatch between organizational role identity and organizational domain identity. They also found that role and domain identities can jointly determine whether incumbents adopt the disruptive innovation, and also how rapidly and innovatively they respond to it.

The paper by Cozzolino, Verona and Rothaermel titled "Unpacking the Disruption Process: New Technology, Business Models, and Incumbent Adaptation" explores how an incumbent organization managed to adapt its business model in response to ongoing disruption. Their longitudinal study spanning over two decades (1995-2017) sheds light on this important process by analyzing how a major Italian news media publisher reacted first to the advent of the internet, a disruptive technology, and then to the entry into its industry of 
challengers with disruptive business models based on the internet. They examine how the incumbent first experimented somewhat unsuccessfully with the opportunities afforded by the internet, then entered into alliances with others when threatened by challengers, and finally ended up adopting an open platform-based business model to more efficiently leverage emerging opportunities by melding internal and external knowledge and resources.

While these three papers document and theorize on the challenges that incumbents confront in interpreting and then responding to threats posed by disruptive innovations, the next two papers speak to the external challenges that firms confront in introducing disruptive innovations. In their paper titled "Disruption in platform-based ecosystems", Ozalp, Cennamo and Gawer study intergenerational transitions in platform-based technologies as instances of potentially disruptive innovations at the ecosystem level. In the video game console industry, they found that technologically complex platforms struggle the most in attracting timely and high-quality complements in the early phases of an intergenerational transition and show a pattern of defection of complementors toward less-complex rival platforms. Their study extends the mainstream theory of disruption to apply to platformbased ecosystems by highlighting the key roles played by complementors in enabling disruption.

The paper by Zietsma, Ruebottom and Shantz explores the challenges that newentrant entrepreneurs may confront in introducing disruptive innovations. Approaching the topic from an institutional theory perspective, the authors examined incumbent resistance to a potentially disruptive innovation - the introduction of clean energy technology in Canada even though it was perceived as being socially beneficial. In their paper titled "Unobtrusive maintenance: Temporal complexity, latent category control and the stalled emergence of the cleantech sector", the authors discuss how incumbents (i.e., traditional utilities) were able to engage in 'unobtrusive maintenance' by enacting 'legitimizing stabilizing mechanisms' in 
their socio-technical regime's infrastructure. Such maintenance work by incumbents delayed the emergence of the disruptive clean technology, thereby creating temporal complexity and associated challenges for clean tech entrepreneurs.

Concluding the special issue on a positive note (for disruptors) is the study by Snihur, Thomas and Burgelman, which explores Salesforce.com's successful disruption of the enterprise CRM software industry. Taking an ecosystem and a business model adaptation perspectives, the authors introduce the notion of disruptor's gambit wherein the new-entrant challenger is forthright from the very beginning about its intention to disrupt and assume a leadership position in the industry. In their paper titled "An ecosystem-level process model of business model disruption: The disruptor's gambit", the authors describe how the disruptor then delivers on its intention by employing dynamic framing and continual business model adaptation to draw customers and complementors away from the incumbent and forge a vibrant ecosystem around its own technology.

In sum, the papers featured in this special issue employ different perspectives to explore the phenomenon of disruptive innovations. Common across them is an emphasis on the following points: (1) that we need to pay attention not just to incumbents and disruptors, but also to other key ecosystem stakeholders; (2) that disruption is a process; and (3) that there are many challenges, complexities and paradoxes involved. With respect to theory, the papers traverse and connect diverse yet complementary literatures including disruption theory, ecosystems, framing, institutional theory, identity theory, and process theory.

\section{CONCLUSION}

Many years ago, Peter Drucker noted, "The greatest danger in times of turbulence is not turbulence itself, but to act with yesterday's logic.” By any measure, we are living in an era of transformational change brought about by digitalization, industry convergence, overlapping ecosystems, inter-penetrating platforms. Such an era requires new approaches on 
the part of firms, regulators, market-players and the society at large to deal with ongoing disruptions and attendant changes. Researchers need new ways to empirically study and theorize on such phenomena. Practitioners need novel reflective tools, as opposed to simplified prescriptions, to help them better deal with disruptions proactively and reactively. We have offered preliminary thoughts on how to better engage with these developments and, in doing so, extended the remit and relevance of extant theory.

Indeed, this special issue is an invitation to both researchers and practitioners to explore what it means to research and manage in this era of continual disruption. No longer can we wait for phenomena to stabilize, or for all the data to be available before we begin our empirical analysis or theorization. Instead, as John Seely Brown, the former Chief Scientist at Xerox PARC and an academic in his own right, noted, “...business is always conducted in [a] 'fog or reality.' You're forever aiming at targets you can't see, or you don't understand, or change as a result of things you do" (1997: 99).

How can we theorize and practice in and through this fog that seems to get thicker because of the "things we do"? Instead of offering a laundry list of research and practice topics, we provide a generative way to approach this issue. Specifically, we suggest that interesting research questions can be generated at the intersection of topics such as platforms, ecosystems, co-opetition, to name a few, and perspectives such as evolutionary, relational temporal and framing that lead to a performative approach. For instance, at the intersection of coopetition and relational/temporal perspectives, we could ask: How might the balance between cooperation and competition among firms shift over time as disruption unfolds? Or, at the intersection of ecosystems and performativity, we could ask: How might disruptors frame their disruptive innovations (internally and to ecosystem members), and how might such framing change over time? And at the intersection of the temporal, framing and performative perspectives, one might as: How do innovators make sense of the past, perform 
the future, even as they act in the present? These are but indicative questions that can further advance our understanding of disruptive innovation as a performative process. 


\section{REFERENCES}

Abernathy, W. J. and Clark, K. B. (1985). 'Innovation: Mapping the winds of creative destruction'. Research policy, 14, 3-22.

Adner, R. (2012). The wide lens: A new strategy for innovation. Penguin UK.

Adner, R., and Kapoor, R. (2010). 'Value creation in innovation ecosystems: How the structure of technological interdependence affects firm performance in new technology generations'. Strategic Management Journal, 31(3), 306-333.

Ansari, S. M., and Garud, R. (2009). 'Intergenerational transitions in technological ecosystems: The case of mobile telephony'. Research Policy. 38: 382-392.

Ansari, S., Garud, R., and Kumaraswamy, A. (2016). 'The disruptor's dilemma: TiVo and the US television ecosystem'. Strategic Management Journal, 37(9), 1829-1853.

Ansari, S., and Krop, P. (2012). 'Incumbent performance in the face of a radical innovation: Towards a framework for incumbent challenger dynamics'. Research Policy, 41(8), $1357-1374$

Austin, J.L. (1962). How to do things with words. Oxford: Clarendon Press

Benner, M. J., and Tripsas, M. (2012). 'The influence of prior industry affiliation on framing in nascent industries: The evolution of digital cameras'. Strategic Management Journal, 33(3), 277-302.

Bijker, W. (1995). Of bicycles, bakelites, and bulbs: Towards a theory of sociotechnical change. Cambridge, MA: MIT Press.

Brandenburger, A. M., and Nalebuff, B. J. (1996). Co-opetition. Currency Doubleday.

Brown, J. S. (1997). Changing the game of corporate research: Learning to thrive in the fog of reality. In Garud, R., Nayyar, P. R., \& Shapira, Z. B. (Eds.). Technological innovation: Oversights and foresights: 95-110. Cambridge University Press.

Callon, M. (1998). 'An essay on framing and overflowing: economic externalities revisited by sociology'. The Sociological Review, 46(S1), 244-269.

Christensen, C. (1997). The Innovator's Dilemma: When New Technologies Cause Great Firms to Fail. Cambridge, MA: Harvard Business School Press.

Christensen, C. (2006). 'The ongoing process of building a theory of disruption'. Journal of Product Innovation Management, 23, 39-55.

Christensen, C., Raynor, M. and McDonald, R. (2015). 'What is disruptive innovation?'. Harvard Business Review, December, 44-53.

Coyne, W. E. 1999. Foreword. In A. H. Van de Ven, D. E. Polley, R. Garud, and S. Venkataraman, The Innovation Journey. New York: Oxford University Press, vii-viii.

Daft, R. L., and Lengel, R. H. (1986). 'Organizational information requirements, media richness and structural design'. Management Science, 32(5), 554-571.

Danneels, E. (2011). 'Trying to become a different type of company: Dynamic capability at Smith Corona'. Strategic Management Journal, 32(1), 1-31.

Danneels, E. (2004). 'Disruptive technology reconsidered: A critique and research agenda'. Journal of Product Innovation Management, 21(4), 246-258.

Dosi, G. (1982). 'Technological paradigms and technological trajectories'. Research Policy, 11: $147-62$.

Dougherty, D. (2016). Taking advantage of emergence: Productively innovating in complex innovation systems. Oxford University Press.

Dougherty, D., \& Dunne, D. D. (2011). Organizing ecologies of complex innovation. Organization Science, 22(5), 1214-1223.

Emirbayer, M., and Mische, A. 1998. 'What is agency?' American Journal of Sociology, 103: 962-1023. 
Entman, R. M. (1993). 'Framing: Toward clarification of a fractured paradigm'. Journal of Communication, 43(4), 51-58.

Faems, D., Van Looy, B.V. and Debackere, K. (2005). 'Interorganizational Collaboration and Innovation: Toward a Portfolio Approach', Journal of Product Innovation Management $22(3), 238-250$.

Gans, J. (2016). The disruption dilemma. MIT Press.

Garud, R. and Gehman, J. 2012. 'Metatheoretical Perspectives on Sustainability Journeys:

Evolutionary, Relational and Durational'. Research Policy, 41: 980-995.

Garud, R., Gehman, J. and Giuliani, A. 2018. 'Why not take a performative approach to entrepreneurship?' Journal of Business Venturing Insights. 9: 60-64.

Garud, R., Gehman, J., and Kumaraswamy, A. (2011). Complexity arrangements for sustained innovation: Lessons from 3M Corporation. Organization Studies, 32(6), 737767.

Garud, R., Gehman, J., and Tharchen, T. (2017). 'Performativity as ongoing journeys: Implications for strategy, entrepreneurship, and innovation'. Long Range Planning. https://doi.org/10.1016/j.lrp.2017.02.003

Garud, R. and Karnøe, P. (2003) "Bricolage vs. Breakthrough: Distributed and embedded agency in technology entrepreneurship" Research Policy, 32, 277-300.

Garud, R., \& Karunakaran, A. (2018). Process-based ideology of participative experimentation to foster identity-challenging innovations: The case of Gmail and AdSense. Strategic Organization. Vol 16, Issue 3, pp. 273 - 303

Garud, R., and Kumaraswamy, A. (1995). 'Technological and organizational designs for realizing economies of substitution'. Strategic Management Journal, 16(S1), 93-109.

Garud, R., and Munir, K. (2008). 'From transaction to transformation costs: The case of Polaroid's SX-70 camera'. Research Policy, 37(4), 690-705.

Garud, R., Nayyar, P. R., and Shapira, Z. B. (Eds.). (1997). Technological innovation: Oversights and foresights. Cambridge University Press.

Garud, R. and Rappa, M. A. (1994). 'A Socio-Cognitive Model of Technology Evolution: The Case of Cochlear Implants'. Organization Science, 5 (3), 344-362.

Gawer, A., and Cusumano, M. A. (2014). 'Industry platforms and ecosystem innovation'. Journal of Product Innovation Management, 31(3), 417-433.

Gilbert, C. G. (2005). 'Unbundling the structure of inertia: Resource versus routine rigidity'. Academy of Management Journal, 48(5), 741-763.

Glasmeier, A., (1991). 'Technological discontinuities and flexible production networks: The case of Switzerland and the world watch industry'. Research Policy, 20 (5), 469-485.

Gnyawali D, and Park B. (2011). 'Coopetition between giants: collaboration with competitors for technological innovation'. Research Policy, 40(5): 650-663.

Goffman, E. (1974). Frame analysis: An essay on the organization of experience. Cambridge, MA, US: Harvard University Press.

Grimes, M. (2017). 'The pivot: How founders respond to feedback through idea and identity work'. Academy of Management Journal, DOI: 10.5465/amj.2015.0823

Gray, B., Purdy, B. and Ansari, S.( 2015). 'From interactions to institutions: Microprocesses of framing and mechanisms for the structuring of institutional fields'. Academy of Management Review, 40 (1): 115-143.

Gurses, K., and Ozcan, P. (2015). 'Entrepreneurship in regulated markets: framing contests and collective action to introduce pay TV in the US'. Academy of Management Journal, 58(6), 1709-1739.

Hagiu, A. (2014). 'Strategic decisions for multisided platforms'. MIT Sloan Management Review, 55(2), 71. 
Hatch, M. J., and Schultz, M. (2017). Toward a theory of using history authentically: Historicizing in the Carlsberg Group. Administrative Science Quarterly, 62(4), 657697.

Hernes, T. (2008). Understanding organization as process: Theory for a tangled world. London: Routledge.

Iansiti M, Levien R. (2004). The Keystone Advantage: What the New Dynamics of Business Ecosystems Mean for Strategy, Innovation, and Sustainability. Harvard Business School Press: Cambridge, MA

Jacobides M, Knudsen T, Augier M. (2006). Benefiting from innovation: Value creation, value appropriation and the role of industry architectures. Research Policy, 35: 12001221.

Jacobides, M. G., Cennamo, C., and Gawer, A. (2018). 'Towards a theory of ecosystems'. Strategic Management Journal. https://doi.org/10.1002/smj.2904

Kaplan, S., and Tripsas, M. (2008). 'Thinking about technology: Applying a cognitive lens to technical change'. Research Policy, 37(5), 790-805.

Kapoor, R. and Klueter, T. (2015). 'Decoding the adaptability-rigidity puzzle: Evidence from pharmaceutical incumbents' pursuit of gene therapy and monoclonal antibodies'. Academy of Management Journal, 58, 1180-207.

King, A. and Baatartogtokh, B. (2015). 'How useful is the theory of disruptive innovation'. MIT Sloan Management Review, 57, 77-90.

Leonard-Barton, D. (1992). 'Core capabilities and core rigidities: A paradox in managing new product development'. Strategic Management Journal, 13(S1), 111-125.

Leonardi, P. M. (2011). 'Innovation blindness: Culture, frames, and cross-boundary problem construction in the development of new technology concepts'. Organization Science, 22(2), 347-369.

Lepore, J. (2014). 'The disruption machine: What the gospel of innovation gets wrong'. The New Yorker, May 23.

Levinthal, D. A., \& March, J. G. (1993). 'The myopia of learning'. Strategic Management Journal, 14(S2), 95-112.

Lindahl, L. (1998). 'Spence Silver: A scholar and a gentleman'. 3M Today, 15(1), 12-17.

Markides, C. (2006). 'Disruptive innovation: In need of better theory'. Journal of Product Innovation Management, 23, 19-25.

Mead, G. H. (1932). The Philosophy of the Present. Chicago, IL: Open Court Publishing Company.

Moore JF. (1996). The Death of Competition: Leadership \& Strategy in the Age of Business Ecosystems. Harper Business: New York.

Nambisan, S. , Siegel, D. and Kenney, M. (2018), On Open Innovation, Platforms, and Entrepreneurship. Strategic Entrepreneurship Journal. doi:10.1002/sej.1300.

Orlikowski, W. J., \& Gash, D. C. (1994). 'Technological frames-making sense of information technology in organizations. ACM Transactions on Information Systems'. 12(2), 174-207.

Osiyevskyy, O., and Dewald, J. (2015). 'Explorative versus exploitative business model change: the cognitive antecedents of firm-level responses to disruptive innovation'. Strategic Entrepreneurship Journal, 9(1), 58-78.

Parker, G. G., Van Alstyne, M. W., and Choudary, S. P. (2016). Platform Revolution: How Networked Markets Are Transforming the Economy and How to Make Them Work for You. WW Norton \& Company.

Raffaelli, R. 2018. Technology Reemergence: Creating New Value for Old Technologies in Swiss Mechanical Watchmaking, 1970-2008, Administrative Science Quarterly, https://doi.org/10.1177/0001839218778505 
Reinecke, J. and Ansari, S. (2016). Time, Temporality, and Process Studies Edited by Ann Langley and Haridimos Tsoukas in the Sage Handbook of Process Organization Studies. Pp. 404-418.

Ricoeur, P. (1984). Time and Narrative. Chicago, IL: University of Chicago Press.

Ries, E. (2011). The Lean Startup: How Today's Entrepreneurs Use Continuous Innovation To Create Radically Successful Businesses. Crown Books.

Rochet, J. C., and Tirole, J. (2003). 'Platform competition in two-sided markets'. Journal of The European Economic Association, 1(4), 990-1029.

Sakkab, N. Y. (2002). 'Connect \& develop complements research \& develop at P\&G'. Research-Technology Management, 45(2), 38-45.

Santos, F. M., and Eisenhardt, K. M. (2009). 'Constructing markets and shaping boundaries: Entrepreneurial power in nascent fields.' Academy of Management Journal, 52, 643671.

Schumpeter, J. A. (1942/1994). Capitalism, Socialism and Democracy, London, UK: Routledge.

Sood, A., and Tellis, G. J. (2011). 'Demystifying disruption: A new model for understanding and predicting disruptive technologies'. Marketing Science, 30(2), 339-354.

Teece, D. J. (1986). 'Profiting from technological innovation: Implications for integration, collaboration, licensing and public policy.' Research Policy, 15(6), 285-305.

Tellis, G. J. (2006). 'Disruptive technology or visionary leadership?' Journal of Product Innovation Management, 23(1), 34-38.

Thananusak, T. and Ansari, S. 2018. Scholarly communications and digital disruption: The emergence of Altmetrics and Open Access Publishing in Management Studies. Prepared as a chapter in the special issue of Research in the Sociology of Organization on 'The Production of Managerial Knowledge and Organizational Theory: New Approaches to Writing, Producing and Consuming Theory.'

Tharchen, T., and Garud, R. (2017). The emergence of new market categories in stigmatized industries: the case of e-cigarettes. Farrell Center Working Paper.

The Economist (2015). 'Disrupting Mr. Disrupter', November 26, https://www.economist.com/business/2015/11/26/disrupting-mr-disrupter (accessed on May 15, 2018).

Tripsas, M., and Gavetti, G. (2000). 'Capabilities, cognition, and inertia: Evidence from digital imaging'. Strategic Management Journal, 21, 1147-1161.

Tushman, M. L. and Anderson, P. (1986). 'Technological discontinuities and organizational environments'. Administrative Science Quarterly, 31, 439-465.

Usher, A. P. (1954). A History of Mechanical Inventions. Cambridge, MA: Harvard University Press.

Utterback, J. and Abernathy, W. (1975). 'A dynamic model of process and product innovation'. Omega, 33, 639-56.

Van de Ven, A. H. and Garud, R. 1989. "A framework for understanding the emergence of new industries", in R. Rosenbloom and R. Burgelman (Eds.) Research on technological innovation and management policy, Vol. 4. Greenwich, CT: JAI Press, pp. 195-226.

Vuori, T. O., and Huy, Q. N. (2016). 'Distributed attention and shared emotions in the innovation process: How Nokia lost the smartphone battle'. Administrative Science Quarterly, 61(1), 9-51.

Yin, E., Ansari, S., and Akhtar, N. (2017). 'Radical Innovation, Paradigm Shift and Incumbent's Dilemma The Case of the Auto Industry'. Future Studies Research Journal: Trends and Strategies, 9(1), 138-148.

Yoo, Y., Boland Jr, R. J., Lyytinen, K., \& Majchrzak, A. (2012). 'Organizing for innovation in the digitized world'. Organization science, 23(5), 1398-1408. 
Table 1. Papers in this Special Issue

\begin{tabular}{|c|c|c|c|}
\hline Paper Title & Authors & Disruptive phenomenon studied & Summary details \\
\hline $\begin{array}{l}\text { Disruptive Innovation: An } \\
\text { Intellectual History and } \\
\text { Directions for Future Research }\end{array}$ & $\begin{array}{l}\text { Christensen, } \\
\text { McDonald, Altman } \\
\text { and Palmer }\end{array}$ & Not applicable; Review article & $\begin{array}{l}\text { A review of the intellectual history and the evolution of } \\
\text { the study of disruptive innovations. }\end{array}$ \\
\hline $\begin{array}{l}\text { Embracing bewilderment: } \\
\text { Responding to technological } \\
\text { disruption in heterogeneous } \\
\text { market environments }\end{array}$ & $\begin{array}{l}\text { Khanagha, Zadeh, } \\
\text { Mihalache and } \\
\text { Volberda }\end{array}$ & $\begin{array}{l}\text { Ericsson's worldwide initiatives to } \\
\text { contend with the emergence of the } \\
\text { disruptive cloud computing } \\
\text { technology. }\end{array}$ & $\begin{array}{l}\text { Heterogeneous markets perspective; How heterogeneity } \\
\text { in global demand makes it difficult even for a proactive } \\
\text { incumbent to respond to disruption. }\end{array}$ \\
\hline $\begin{array}{l}\text { Why do incumbents respond } \\
\text { heterogeneously to disruptive } \\
\text { innovations? The interplay of } \\
\text { domain identity and role identity }\end{array}$ & $\begin{array}{l}\text { Kammerlander, } \\
\text { Koenig and } \\
\text { Richards }\end{array}$ & $\begin{array}{l}14 \text { German book publishing } \\
\text { companies facing disruption due to } \\
\text { digital publishing }\end{array}$ & $\begin{array}{l}\text { Identity theory perspective; How identity conflicts } \\
\text { between domain and role identities shape the way } \\
\text { incumbents respond to disruptive innovation. }\end{array}$ \\
\hline $\begin{array}{l}\text { Unpacking the Disruption } \\
\text { Process: New Technology, } \\
\text { Business Models, and Incumbent } \\
\text { Adaptation }\end{array}$ & $\begin{array}{l}\text { Cozzolino, Verona } \\
\text { and Rothaermel }\end{array}$ & $\begin{array}{l}\text { Disruption faced by a major Italian } \\
\text { newspaper publisher first due to the } \\
\text { advent of the internet, and then due } \\
\text { to the entry of online publishing } \\
\text { challengers with new business } \\
\text { models }\end{array}$ & $\begin{array}{l}\text { Business model adaptation perspective; How a pro- } \\
\text { active incumbent first struggled to respond to a } \\
\text { disruptive innovation on its own and through alliances, } \\
\text { but eventually adapted by moving from a closed } \\
\text { business model to an open platform-based business } \\
\text { model. }\end{array}$ \\
\hline $\begin{array}{l}\text { Disruption in platform-based } \\
\text { ecosystems }\end{array}$ & $\begin{array}{l}\text { Ozalp, Cennamo } \\
\text { and Gawer }\end{array}$ & $\begin{array}{l}\text { Disruptive transitions between } \\
\text { successive generations of video- } \\
\text { game platforms. }\end{array}$ & $\begin{array}{l}\text { Platform-based ecosystem perspective; How complexity } \\
\text { of technology influences support from complementors } \\
\text { in effecting disruptive intergenerational platform } \\
\text { transitions. }\end{array}$ \\
\hline $\begin{array}{l}\text { Unobtrusive maintenance: } \\
\text { Temporal complexity, latent } \\
\text { category control and the stalled } \\
\text { emergence of the cleantech sector }\end{array}$ & $\begin{array}{l}\text { Zietsma, } \\
\text { Ruebottom and } \\
\text { Shantz }\end{array}$ & $\begin{array}{l}\text { Disruption of traditional power } \\
\text { utilities in Canada due to the } \\
\text { emergence of clean technologies }\end{array}$ & $\begin{array}{l}\text { Institutional theory perspective; How new-entrant } \\
\text { entrepreneurs introducing even a socially beneficial } \\
\text { disruptive innovation can be stalled through institutional } \\
\text { maintenance work performed by incumbents. }\end{array}$ \\
\hline $\begin{array}{l}\text { An ecosystem-level process } \\
\text { model of business model } \\
\text { disruption: The disruptor's } \\
\text { gambit }\end{array}$ & $\begin{array}{l}\text { Snihur, Thomas } \\
\text { and Burgelman }\end{array}$ & $\begin{array}{l}\text { Disruption in the enterprise } \\
\text { customer relationship management } \\
\text { (CRM) software industry } \\
\text { (Salesforce.com vs Siebel) }\end{array}$ & $\begin{array}{l}\text { Ecosystem, framing and business model adaptation } \\
\text { perspectives; How a disruptor makes its disruptive } \\
\text { intentions known from the very beginning and delivers } \\
\text { on this intention by employing dynamic framing and } \\
\text { business model adaptation to forge an ecosystem around } \\
\text { its innovation. }\end{array}$ \\
\hline
\end{tabular}

